inScience

through time and space
Жамият ва инновациялар -

Общество и инновации -

Society and innovations

Journal home page:

https://inscience.uz/index.php/socinov/index

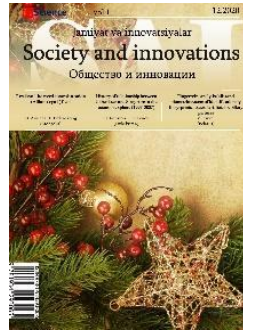

\title{
The expression and essence of social functions of the state
}

\section{Umidzhon KODIROV ${ }^{1}$}

Academy of the Ministry of Internal Affairs of the Republic of Uzbekistan

\begin{tabular}{l} 
ARTICLE INFO \\
\hline Article history: \\
Received September 2020 \\
Received in revised form \\
15 October 2020 \\
Accepted 15 November \\
2020 \\
Available online \\
31 December 2020
\end{tabular}

\section{Keywords:}

State

Function

Social function

Social sphere

Social protection

Social assistance.

\begin{abstract}
The purpose of the work is to gain an understanding of the social function of the state, to understand the relationship between the social and other functions of the state, to improve the social function of the state. The article uses comparativelegal, systematic, analytical, synthesis methods. The article offers suggestions for creating a legal framework for the social function of the state.
\end{abstract}

2181-1415/C) 2020 in Science LLC.

This is an open access article under the Attribution 4.0 International (CC BY 4.0) license (https://creativecommons.org/licenses/by/4.0/deed.ru)

\section{Давлатнинг ижтимоий функцияси тушунчаси ва мохияти}

\begin{tabular}{l}
\hline Калит сўзлар: \\
Давлат \\
Функция \\
Ижтимоий функция \\
Ижтимоий соха \\
Ижтимоий химоя \\
Ижтимоий ёрдам
\end{tabular}

\begin{abstract}
АННОТАЦИЯ
Ишнинг мақсади давлатнинг ижтимоий функцияси тўғрисида тушунчага эга бўлиш, давлатнинг ижтимоий функциясининг давлатнинг бошқа функциялардан ўзаро нисбатини англаш, давлатнинг ижтимоий функциясини такомиллаштириш. Мақолада қиёсий-хуқуқий, тизимли, анализ, синтез усулларидан фойдаланилган. Ишда давлатнинг ижтимоий функциясинининг хуқуқий асосларини яратиш бўйича таклифлар берилган.
\end{abstract}

\footnotetext{
${ }^{1} \mathrm{PhD}$, associate professor, Academy of the Ministry of Internal Affairs of the Republic of Uzbekistan, Tashkent, Uzbekistan
} 


\section{Понятие и сущность социальных функций государства}

Ключевые слова:

Государство

Функция

Социальная функция

Социальная сфера

Социальная защита

Социальная помощь.

\section{АННОТАЦИЯ}

Цель работы заключается в составлении понятия о

социальной функции государства, в осознании соотношения социальной и других функций государства, в совершенствовании социальной функции государства. В статье использованы такие методы как сравнительноправовой, системный анализ, синтез. В статье даны предложения по созданию правовых основ социальной функции государства.

\section{INTRODUCTION}

Determining the main directions of its activity in the process of formation and development is natural for any state. Uzbekistan has set itself the main goal of building a democratic state based on the rule of law and the free civil society after gaining its independence. Today, one of the topical tasks is the mechanism of social protection as compatible with this goal.

Indeed, the task of social protection of the population in the country has always been topical. In this regard, the President Sh. M. Mirziyoev pays special attention to the priorities of the social sphere in the Strategy of Actions for the five priority areas of development of the Republic of Uzbekistan for 2017-2021, which proposes the gradual increase in employment and real incomes, improvement of social protection, welfare and health care, increasing the socio-political activity of women, the implementation of targeted programs to build affordable housing, road-transport, development and modernization of engineering-communications and social infrastructure that improve the living conditions of the population, development of education and science, improvement of the state youth policy.

It would be expedient to dwell on the concept of the function of the state before focusing on the expression of the social function of the state. The study of the question of the concept of state function has always been controversial. This is due to the reason of the theoretical complexity of the issue. The word "function" translates from Latin to mean "to execute", "to perform" [1].

Taking into consideration the complexity of this phenomenon in terms of its structure, its essence is defined as a philosophical category in the research of the category of "state function" in the theory of state. Such an approach to the function of the state shows that there are other concepts than the dominant concept, which is realized as the main areas of activity in which it carries out the tasks facing the state.

\section{THE DEGREE OF THE STUDIED PROBLEM}

Generally, the word "function" is not only used in law sciences, but also commonly used in other fields. Therefore, it is necessary to distinguish the expression of "state function" from other similar concepts. The reason is that there is no consensus among law scholars in interpreting the expression of the state function. For instance, F. V. Fetyukov, who conducted research on the function of the state, argues that the state functions should be understood as the main directions of state activity, and the understanding of state 
functions is its social purpose, the systematic influence on social relations in certain areas[2]. Professors V.V. Lazarev and S.V. Lipen describe "The function of the state is the main direction of activity to address the facing tasks" [3], while professors K.I. Matuzov and A.V. Malko clarify that "the function of the state is the main directions inherent in the foreign and internal activities of the state, which are reflected and defined on the basis of the class and universal nature of the state" [4].

The Uzbek scientist, Professor Kh. T. Odilkoriyev, defined the state function as "the main, vital direction of the state's social functions" [5], while Professor Z.M.Islamov highlights "The state function is the direction of activity, but never the activity itself" [6].

Professors A. Saidov and U. Tozhikhonov[7] put forward the same opinion. Thus, there is no single thought in the law literature on the concept of state function. Nevertheless, all researchers express that the function of the state determines the essence, social goals, tasks of the state.

In addition to the above considerations, it should be noted that the function of the state is undoubtedly appropriate with its social goals, but they are not similar concepts. The function of the state is a complex concept in its content, which includes the theoretical study of the social goals of the state and, consequently, it comprises the activities of the state in social life, its objectives in the practical activities of the state as elements of the function of the state.

The Republic of Uzbekistan has been operating in accordance with the international rules and universal principles in the social sphere from the initial days of its independence. The Universal Declaration of human rights, the International Pact on economic, social and cultural rights, and the International Pact on civil and political rights are primarily quintessential[8].

Social protection (welfare state) is based on international law norms and standards as one of human rights, and therefore its main principles are rooted in universal values. First of all, the Universal Declaration of human rights, which is an international legal regulation, states that everyone has the right to adequate social welfare in case of financial destitution. Particularly, according to the Declaration, a person is included in the list of social risks that is the basis for obtaining social assistance in any case where s/he is in need of assistance for objective reasons beyond her/his control.

If we pay attention to the essence and content of the social policy pursued since the first days of independence of the Republic of Uzbekistan up to present, we can see that social protection has always been in the focus of attention and the most significant part of budget expenditures has always been allocated for social purposes in our country.

Social protection of the population in need of social assistance has been carried out in different ways, such as, at the expense of different sources and by various subjects. In particular, recognizing that the expansion of non-governmental forms of social welfare is a priority, especially in the process of building the rule of law and strong civil society, the state continues to prioritize socialization, which in the transition period assumes the primary reform responsibility and one of the main tasks is strong social protection.

The completely new material-legal and methodological approach to the definition and guarantee of socio-economic rights of the individual in the social sphere are embodied in our main encyclopedia, that is the Constitution of the Republic of Uzbekistan. For example, the Article 2 of the Constitution stipulates, "The state shall express the will of the 
people and serve their interests. State bodies and officials shall be accountable to the society and citizens", while the Article 7 states that the people are the sole source of state power, and the interests of the people take precedence over all other norms.

It is necessary to determine the main directions of state activity in the social sphere when we talk about the social function of the state. Namely, it is necessary to determine what the newly formed state should implement first in its initial stages of development, and what the state organs and organizations should focus on firstly. Accordingly, the scientific analysis of the issue of the social function of the state in the stages of building the rule of law in independent Uzbekistan is of great theoretical and practical importance.

The social function of the state is oriented to ensure the social protection of individual, worthwhile living conditions for all members of society, regardless of whether directly participate in the creation of material wealth or not.

The provision of material wealth is carried out in addition to the free equivalent exchange between producers and consumers in the state governed by the rule of law. The social policy of the state, first of all, requires its distribution regardless of the share of labor added to the creation of social wealth, in order to ensure a decent standard of living for those who for various objective reasons abstain work in full time (patients, disabled, the old, students, children).

Secondly, the government allocates the necessary funds for health, cultural recreation, education, housing, transport and communication for their flawless performance. The state enables to some extent the proper realization of the rights of citizens to health care, recreation, housing, education, and the enjoyment of cultural achievements, that is considered their social rights, through such opportunities. All citizens of the state should use such rights to the fullest extent possible. Democratic state guarantees clear social protection to all those who are economically vulnerable, and constantly increases the funds allocated for the social needs of the entire population of the country. The state will be able to pursue the fair social policy towards the population of the country in case the creators of material and spiritual wealth have freedom and economic independence[8].

The social goals of the state include class and general social goals when evaluating from the historical point of view. The social function of the state also includes "national" goals and reflects the "social goals of the state". The directions of the state activity, namely, its function, "programming" activity are determined by the society, as highly organized system. This is because the state is a "servant" of society, an institution created by society, mobilized by society to perform the tasks and functions assigned to it. It is about the role of the state in society, its social function performance[9].

Russian scientist D.A. Kamilov emphasizes that the implementation of the social function of the state is directly related to the public, as well as the importance of social stability and peace in society for the well-being of citizens, their material, social and intellectual needs[10].

The state contributes to the social development of individuals, enriches their personality and, as a result, contributes to the sustainability of the historical process to the certain extent, through its social function. The social function of the state performs the specific function of the unifying principle for the people. This function ensures that each person belongs to and participates in public affairs. The stronger the social function of the 
state, the sharper the contradiction between the general and individual essence of the person.

In our opinion, the social function of the state is to provide citizens with decent standard of living, the main direction of the activities carried out in the social sphere of public relations. The social function of the state is the state policy in the social sphere of society, which is expressed in the system of measures taken by the state in the field of education, health and social security in order to develop the general essence of human being. The state policy is responsible for qualitatively population growth in the field of social security, education, healthcare system and is aimed at developing the general essence of the individual. Education, as a social institution is a system of teaching and learning and characterized by the subordination of social needs and the performance of the most important social functions. Education is the most important element of spiritual production and generally, is the condition for the growth of the country`s population, the main feature of education is the growth of the individual and social relations.

The social function of the state emerged in the early stages of state development in the form of general principles of state activity or in the form of economic functions. It should be noted that the social function is a state activity that has been inherent in it since the formation of statehood in general. The social functions of the state appear during its evolutionary development unlike the state functions specific to any state.

The responsibility for the protection of the humanity (tribe) was placed on the leaders, councils of elders (ruling groups) in period of the state was not yet historically formed.

It was appeared owing to the formal contract or common legal tradition. The task of the state as the official representative of humanity is to prevent the destruction and disintegration of the foundations of society. The state is responsible for creating the conditions for the improvement of humanity and cannot be left out of this process. Even the history of humankind is the history of growing individuality and freedom, the boundaries of this process are determined by social conditions, and limits the possibilities of individuals striving for self-realization.

It is the expression of the separation of state power from the people from the time of the establishment of the state, and must protect the interests of society by creating appropriate (predominantly material) circumstances. Thus, political power, from the point of view of the public interest, expands its social base and represents (directly or indirectly) its relationship with the people. The participation of the state in the extension of these opportunities is the essence of its social function.

The emergence and development of social functions of the state is characterized by bilateral process. On the one hand, there is an increase for the social functions at high levels of state development, on the other hand, the amalgamation of social functions into complex functional systems along with legal, political and economic functions.

The ideas about its social purpose, living standards, the content and structure of socio-economic rights of the population, as well as the limits of state intervention in the socio-economic sphere in general and the socio-economic status of the population in particular change with the development of the state.

The development of the social function of the state is reflected in the current legislation; through this, the state regulates social relations. The gradual expansion of human rights and freedoms, in turn, indicates the emergence of new methods of 
developing human essence. The implementation of the social function of the state plays an important role in the activities of the state.

Through this, firstly, the creation of decent living conditions for every human being and the provision of the peace of citizens is supplied, secondly, the provision of social protection for the unemployed, the elderly, the disabled, extended families (family owns many children), orphans is supplied, and thirdly, social justice and harmony in society, as well as the democratic system is strengthened.

\section{CONCLUSIONS}

To conclude, it should be stated that strengthening the organizational-legal framework for social protection of the population, equipping the state governing bodies with the necessary legal documents is an important basis for the proper organization and efficiency of this system.

\section{REFERENCES:}

1. Explanatory dictionary of Uzbek language: about 80 thousand phrases. Volume IV. Mode - Shukr / Responsible editor A. Madvaliev. - T .: "National Encyclopedia of Uzbekistan" State scientific publishing house, 2020. P. 608.

2. Fetyukov F.V. Evolution of thoughts about the meaning and content of the concept of state function // Bulletin of the University of Perm. Law sciences. - 2014. - № 3. P.40.

3. Theory of state and law: textbook for universities // V.V. Lazarev, S.V. Lipen. - 5th ed., Rev. and add. - Moscow: Yurayt Publishing House, 2020. P.88.

4. Matuzov K.I., Malko A.V. Theory of state and law. Textbook. - M .: Yuristov, 2004. Pp.48-66.

5. Theory of state and law: Textbook / Kh.T.Odilkoriyev, I.T.Tulteev and others; prof. Edited by Kh.T. Odilkoriyev. - Tashkent .: Academy of the Ministry of Internal Affairs of the Republic of Uzbekistan, 2009. P.107.

6. Islamov Z.M. Society. State. Law, (questions of theory) Tashkent, ed. "Adolat", 2001. P.223.

7. Saidov A., Tozhdixonov U. Theory of state and law: two volumes. Volume 1., State theory. Academy of the Ministry of Internal Affairs of the Republic of Uzbekistan, 2001. P.191.

8. The Supreme Council of the Republic of Uzbekistan ratified the Universal Declaration of human rights on September 30,1991, the International Pact on economic, social and cultural rights on August 30, 1995, and the International Pact on civil and political rights.

9. Theory of state and law: Textbook / Kh.T. Odilkoriyev, I.T.Tulteev and others; prof. Edited by Kh.T. Odilkoriyev. - Tashkent .: Academy of the Ministry of Internal Affairs of the Republic of Uzbekistan, 2009. Pp.112-113.

10. Kamilov D.A. Fundamentals of implementing the social function of the state. Moscow State University named after M.V. Lomonosov. 